\title{
Facile synthesis of two diastereomeric indolizidines corresponding to the postulated structure of alkaloid 5,9E-259B from a Bufonid toad (Melanophryniscus)
}

\author{
Angela Nelson ${ }^{1}$, H. Martin Garraffo ${ }^{2}$, Thomas F. Spande ${ }^{2}$, John W. Daly ${ }^{2}$ \\ and Paul J. Stevenson ${ }^{* 1}$
}

\section{Full Research Paper}

Open Access

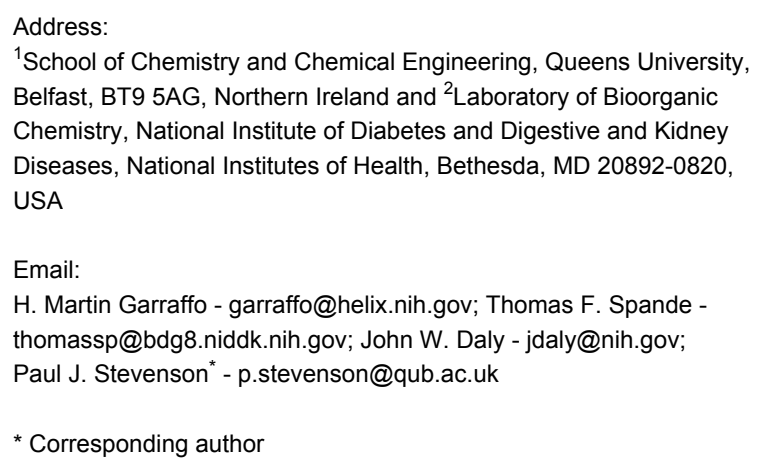

${ }^{1}$ School of Chemistry and Chemical Engineering, Queens University, Belfast, BT9 5AG, Northern Ireland and ${ }^{2}$ Laboratory of Bioorganic Chemistry, National Institute of Diabetes and Digestive and Kidney Diseases, National Institutes of Health, Bethesda, MD 20892-0820, USA

Email:

H. Martin Garraffo - garraffo@helix.nih.gov; Thomas F. Spande thomassp@bdg8.niddk.nih.gov; John W. Daly - jdaly@nih.gov; Paul J. Stevenson* - p.stevenson@qub.ac.uk

* Corresponding author

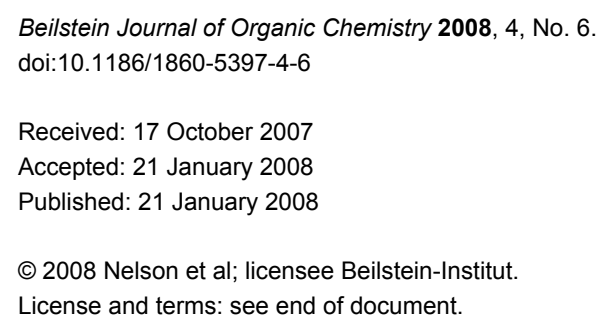


cation undergoes a retro Diels-Alder fragmentation losing an alkene thus identifying the mass of the $\mathrm{C} 8$ substituent. Once the gross structure has been assigned, analysis of the vapor-phase infrared spectrum, particularly the Bohlmann bands, allows assignment of the relative configuration of the chiral centres at $\mathrm{C} 5$ and C9. When the two hydrogens on C5 and C9 are both axial (trans anti-parallel to the $N$ lone pair), designated as $5,9 Z$ (Figure 1), the presence of a strong, sharp Bohlmann band at approximately $2789 \mathrm{~cm}^{-1}$ confirms this relative configuration. In the alternative diastereoisomer when one hydrogen is axial and the other equatorial, designated as $5,9 E$, the Bohlmann band is weak and is shifted to $2810 \mathrm{~cm}^{-1}$. Most 5,8-disubstituted indolizidines detected in frog skin extracts have the $5,9 \mathrm{Z}$ relative configuration, with $259 \mathrm{~B}$ being very unusual in that it has the 5,9E relative configuration. Not surprisingly then, with the exception of the synthesis of two $5,9 E$ diastereomers of the natural $5,9 Z-223 \mathrm{~V}$ [5], most of the synthetic effort has been directed towards the 5,9Z isomers and this has resulted in a large number of elegant approaches to these indolizidines [6-35].

\section{Results and Discussion}

The absolute configurations of $5,9 Z-203 \mathbf{A}$ and $5,9 Z-235 \mathbf{B}^{\prime}$ (Figure 1) and several other such 5,9Z indolizidines are known [2]. Thus, in analogy to such $5,9 Z$ indolizidines it might be anticipated that for the 5,9E indolizidines the stereochemistry at $C 9$ will also be $R$. We now report an enantioselective synthesis of the tentative structure postulated for ent-indolizidine $5,9 E$ 259B, which is outlined in Scheme 1 using $(S)$-pyroglutamic acid as the chiral starting material. The synthesis is extremely short, robust, does not utilise any protecting groups, appears to be completely diastereoselective at $\mathrm{C} 5$ and gives both diastereoisomers at $\mathrm{C} 8$.

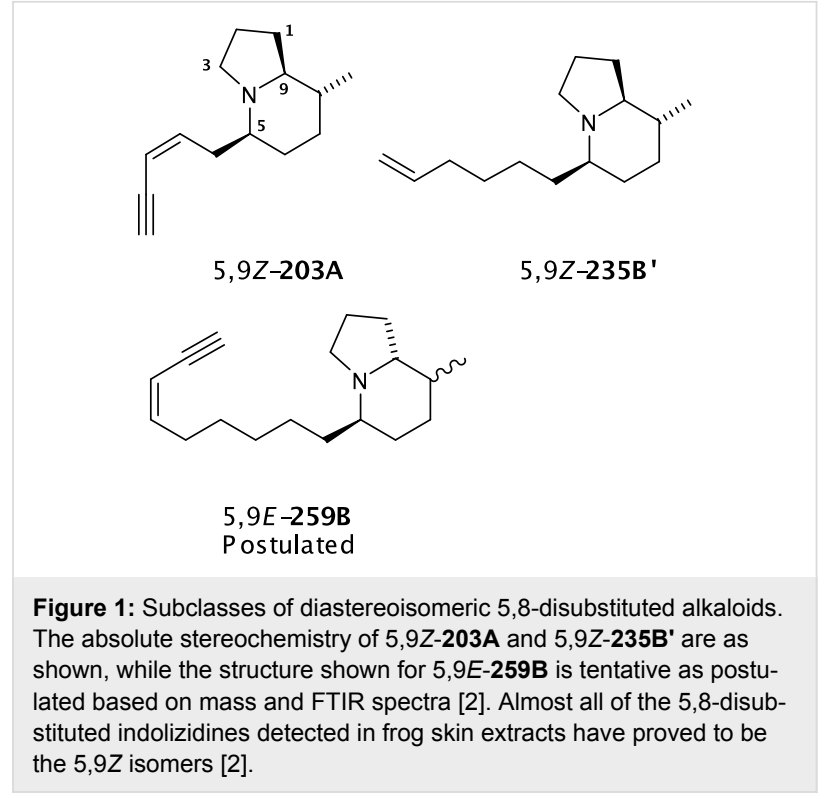

Reaction of ( $S$ )-ethylpyroglutamate with an excess of methyl magnesium iodide gave the water soluble tertiary alcohol $\mathbf{1}$ in $96 \%$ yield. 7-Oxoheptanoic acid methyl ester was prepared by the literature procedure [36], by ozonolysis of 1-methoxycycloheptene, and then condensed with the amidoalcohol $\mathbf{1}$ with azeotropic removal of water to give the $\mathrm{N}, \mathrm{O}$-acetal $\mathbf{2}$ in $71 \%$ yield as a single diastereoisomer. It is likely that allylic strain of the lactam carbonyl group leads to the alkyl group preferentially occupying a pseudo-axial position [37-40]. Reaction of $\mathrm{N}, \mathrm{O}$-acetal 2 with trimethylallyl silane and titanium tetrachloride at room temperature for two days gave the product $\mathbf{3}$ in $68 \%$ yield. The alternate diastereoisomer could not be detected by NMR spectroscopy in the crude reaction mixture. Product 3 formally arises by attack of trimethylallyl silane from<smiles>O=C1CCC([O+])N1</smiles>
(i)
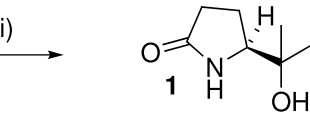<smiles>COC(=O)C=CC=O</smiles><smiles>CO[C@H]1O[C@H](C)[C@@]2(C)CCC(=O)N12</smiles>

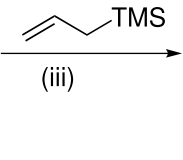<smiles>C=CCC(C)(C)N1C(=O)CCC1C(C)(C)O</smiles><smiles>[3H]C1CC[C@@H](C)C2CCCN12</smiles>
(viii)<smiles>C[C@H]1CCC([As])N2CCC[C@@H]12</smiles>

(vi) (vii)<smiles>COC(=O)C([As])C1CC=C(C)C2CCC(=O)N21</smiles><smiles>C#CC1CCCCC1</smiles>

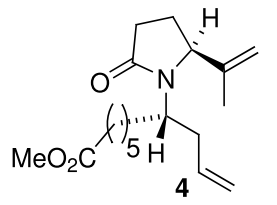

Scheme 1: Reagents: (i) MeMgl. 96\% (ii) PTSA $71 \%$. (iii) $\mathrm{TiCl}_{4} \mathrm{CH}_{2} \mathrm{Cl}_{2} 25^{\circ} \mathrm{C} 3 \mathrm{~d} 68 \%$. (iv) $\mathrm{MsCl}, \mathrm{Et}_{3} \mathrm{~N}, \mathrm{THF}-40{ }^{\circ} \mathrm{C}, 74 \%$. (v) $\mathrm{Grubbs}$ catalyst, $25^{\circ} \mathrm{C}$ $\mathrm{CH}_{2} \mathrm{Cl}_{2}, 90 \%$. (vi) $\mathrm{H}_{2} \mathrm{MeOH} \mathrm{Pt} / \mathrm{C} 79 \%$. (vii) $\mathrm{LiAlH}_{4}, \mathrm{AlCl}_{3}, 73 \%$. (viii) (a) Dess Martin periodinane, $77 \%$. (b) $\left.\mathrm{Ph}_{3} \mathrm{P}^{+} \mathrm{CH}_{2} \mathrm{I} \mathrm{I}^{-}, \mathrm{NaN}(\mathrm{SiMe})_{2}\right)_{2} 51 \%$. (c) $\mathrm{TMS}$ acetylene, $\mathrm{Cul}, \mathrm{Pd}\left(\mathrm{Ph}_{3} \mathrm{P}\right)_{3}$, Et ${ }_{3} \mathrm{~N}$ then $\mathrm{K}_{2} \mathrm{CO}_{3} \mathrm{MeOH}, 69 \%$. 

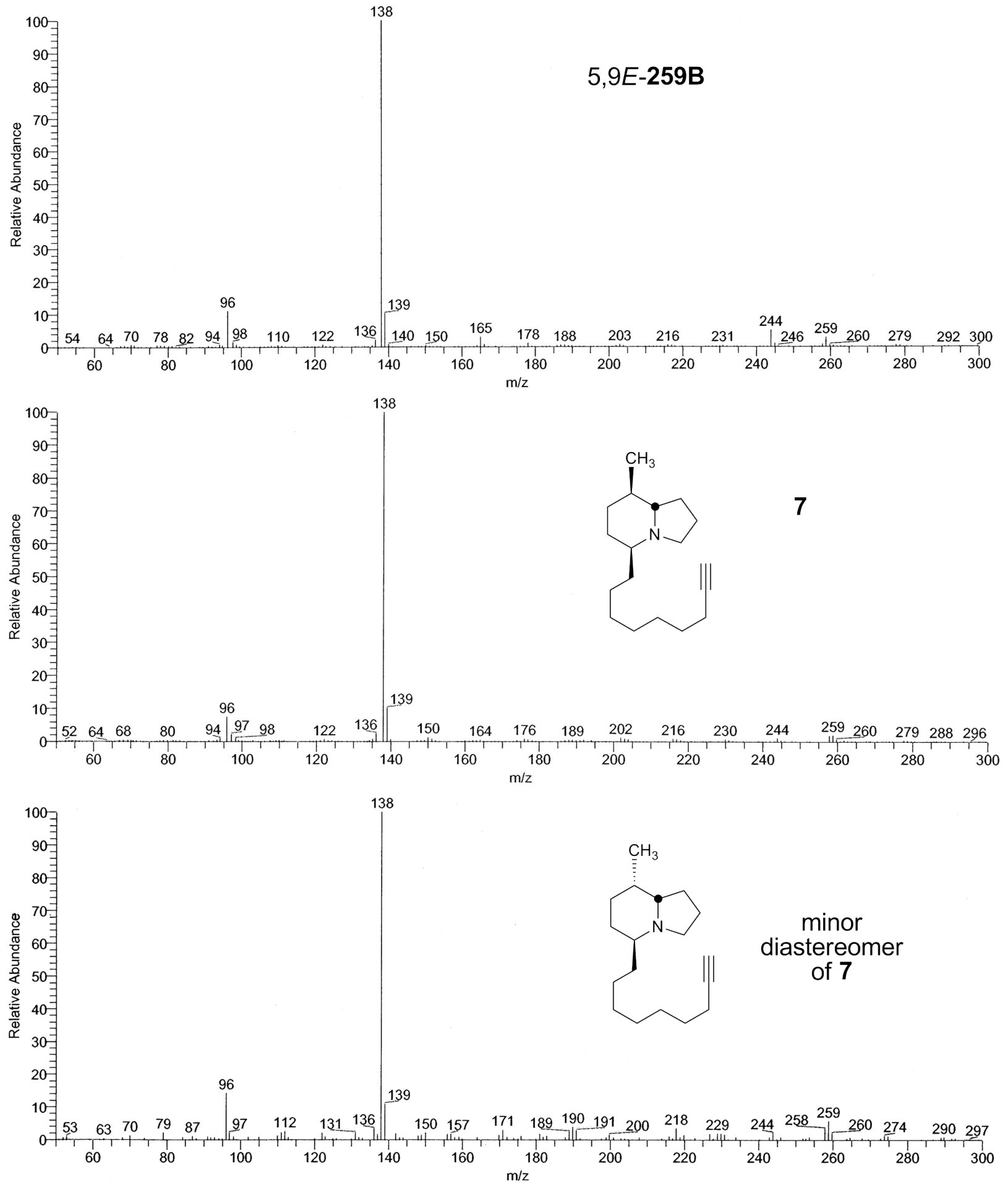

Figure 2: EIMS spectra of a) natural 5,9E-259B, b) synthetic 7, and c) synthetic minor diastereomer of 7 . Structures are shown with relative configuration. 

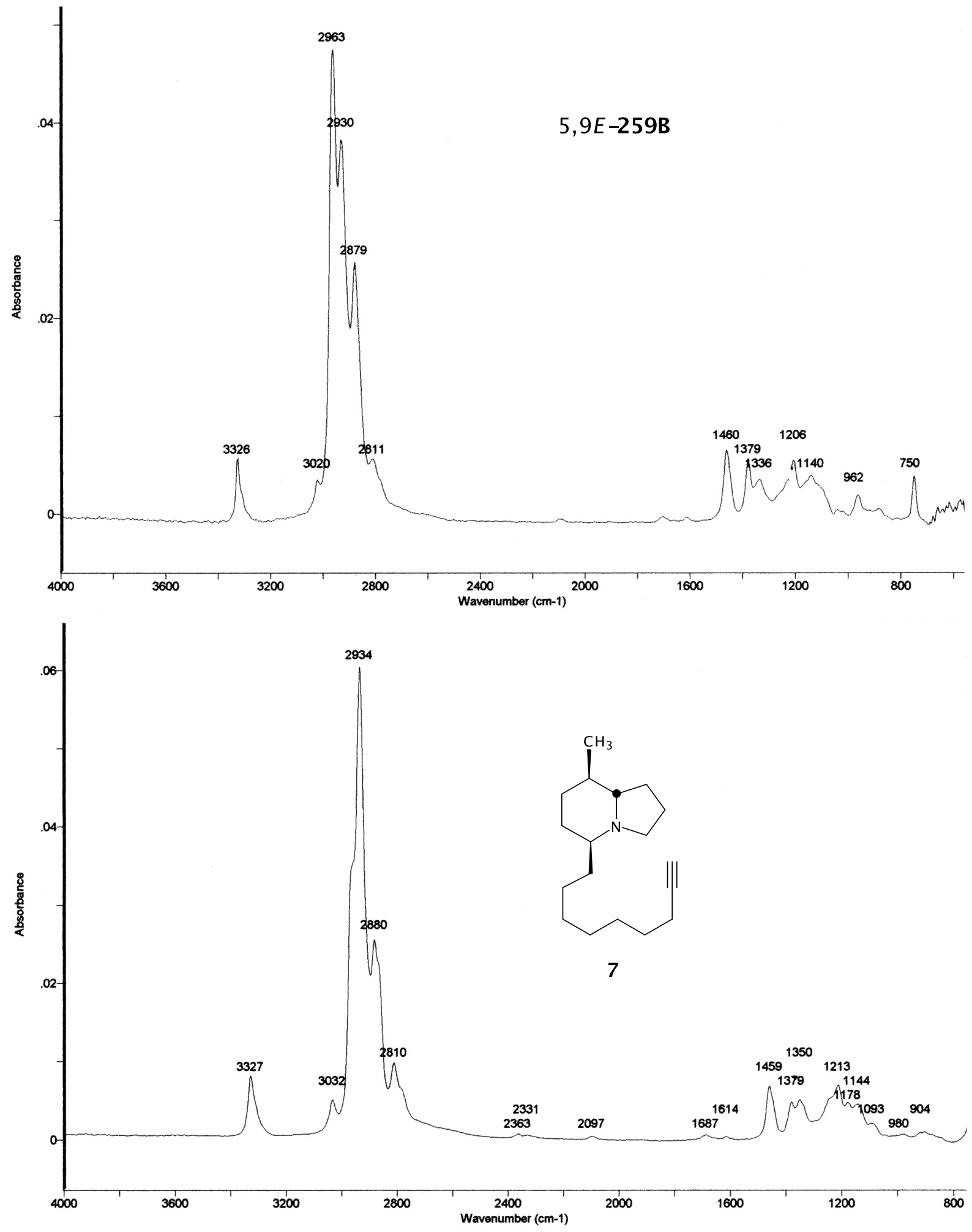

Figure 3: Vapor-phase FTIR spectra of a) natural 5,9E-259B, and b) synthetic 7. Structure shown with relative configuration. 
the least hindered face of the thermodynamically less stable $Z$-iminium ion and the mechanistic details of this intriguing transformation will be published elsewhere in due course. Onepot dehydration of the tertiary alcohol $\mathbf{3}$ was accomplished via the mesylate, and in situ elimination with triethylamine to give the diene $\mathbf{4}$ in $74 \%$ yield. Diene $\mathbf{4}$ smoothly underwent cyclisation to indolizidinone $\mathbf{5}$ when treated with Grubbs' first generation catalyst $[41,42]$. Analysis of the spectral properties of indolizidine $\mathbf{5}$ was considered convenient to confirm the stereochemistry at $\mathrm{C} 5$. It is known that in indolizidinones, with a carbonyl group at $\mathrm{C} 3$, the $\mathrm{C} 5$ hydrogen in the equatorial position will have an anomalously high chemical shift in NMR due to it lying in the deshielding cone of the lactam carbonyl group $[5,37,38,43,44]$. In the present case, the proton at C5 has a chemical shift at $\delta 4.24 \mathrm{ppm}$ and the corresponding proton in similar indolizidinones with the $5,9 \mathrm{Z}$ relative configuration has a chemical shift at about $\delta 3.27 \mathrm{ppm}$. Reduction of the alkene 5 with hydrogen and a heterogeneous catalyst gave the product indolizidines as a mixture of $\mathrm{C} 8$ diastereoisomers. When platinum oxide was used as catalyst, a 1:1 mixture of diastereoisomers resulted, but when platinum-on-carbon was employed, a 4:1 mixture was produced with the isomer corresponding to 6 (Scheme 1) predominating. We have previously shown [45], and there is also good literature precedent $[46,47]$, that in indolizidines with unsaturation at $\mathrm{C} 7-\mathrm{C} 8$ there is a tendency for the addition reactions to occur on the concave face, although this obviously will be influenced by the presence of other substituents. In the present case, there is an additional axial substituent at $\mathrm{C} 5$, which again would encourage reaction from the concave face. Although the mixture of isomers proved inseparable at this stage, the relative configuration at $\mathrm{C} 8$ in both diastereoisomers could be readily assigned by examining the multiplets for the hydrogen at $\mathrm{C} 9$. For the major diastereoisomer the coupling constant $J_{8-9}$ was $9.9 \mathrm{~Hz}$, indicating a trans diaxial arrangement of these hydrogens and for the minor diastereoisomer the corresponding $J$ value was $3.9 \mathrm{~Hz}$. All that remained to complete the synthesis was the reduction of the lactam carbonyl group and the installation of the cis-enyne functionality. Simultaneous reduction of both the ester and the amide gave the alcohol 6. Dess Martin oxidation [48] of the alcohol 6 gave an aldehyde, which on Stork Zhao reaction [49] gave the $Z$-vinyl iodide with a selectivity of 97:3. Finally, Sonogashira reaction [50] of the vinyl iodide with trimethylsilylacetylene followed by removal of the trimethylsilyl group gave synthetic 7. At this stage the $\mathrm{C} 8$ diastereoisomers were separated by flash chromatography, though the minor component was contaminated with triphenyl phosphine / phosphine oxide residue from the Sonogashira reaction.

The two synthetic C8 diastereoisomers were compared to natural $5,9 E-259 \mathrm{~B}$ present in the alkaloid fraction obtained from a bufonid toad, Melanophryniscus stelzneri [51]. The GC mass spectra of the three compounds were very similar (Figure 2). However there was a greater loss of methyl for the natural alkaloid. The GC FTIR spectrum of the major synthetic diastereoisomer 7 differed from the natural $5,9 E-259 \mathrm{~B}$ in the fingerprint region (Figure 3). In addition, the vinyl $\mathrm{C}-\mathrm{H}$ stretching absorption band is at $3020 \mathrm{~cm}^{-1}$ rather than the expected 3032 $3038 \mathrm{~cm}^{-1}$ for a conjugated $\mathrm{CH}=\mathrm{CH}$, as found in synthetic 7 and in the minor diastereomer. Finally, the intense C-H absorption band at $2963 \mathrm{~cm}^{-1}$ in natural $5,9 E-259 \mathrm{~B}$ suggests that two methyls rather than one are present. The corresponding band at $2961 \mathrm{~cm}^{-1}$ is merely a shoulder in the synthetic compounds that contain only one methyl. The GC FTIR spectrum of the minor synthetic isomer was very similar to that of the major isomer 7, but due to a co-emerging contaminant the finger-print region could not be compared and the mixed FTIR is not shown. Remarkably, the GC retention time of the natural 5,9E259B was markedly shorter than those of the two synthetic compounds as follows: Natural 5,9E-259B: $11.01 \mathrm{~min}$; major synthetic isomer 7: $13.01 \mathrm{~min}$; minor synthetic isomer: 13.07 $\min$. These retention times have been slightly adjusted to make them consistent with the retention times reported for the many frog skin alkaloids [2]. After hydrogenation the GC-retention times of the products (MW 265) were changed only slightly with the retention time of the perhydro-derivative of natural $5,9 E$-259B still markedly less than those of the perhydrosynthetics. This result proves that the carbon skeleton of 259B is different to $\mathbf{7}$ and supports the proposal that there is a branch point in the C5 side-chain.

Clearly, a structural revision for $5,9 E-259 \mathrm{~B}$ is needed and it appears most likely that the point of difference is branching on the C5 side-chain. Isolation of 5,9E-259B for NMR spectral analysis will be required to establish the presence and nature of such branching. This hypothesis, if verified, is very significant because branching of the side-chains of 'izidine' alkaloids has been considered unlikely. The only documented case is the 5,6,8-trisubstituted indolizidine 5,9E-249F, isolated for NMR analysis from a dendrobatid frog, Dendrobates auratus, where there is an ethyl branch in the C5 substituent [51]. Further study will be needed to determine what other izidines detected in frog skin extracts have branch points in their side-chains. See Supporting Information File 1 for full experimental data.

\section{Conclusion}

An extremely short entry to the unusual 5,8-disubstituted 5,9Eindolizidine alkaloids has been developed giving a synthetic sample of two possible structures corresponding to the structure postulated for indolizidine alkaloid 5,9E-259B. The synthetic compounds had mass and FTIR spectra similar, but not identical to those of the natural product, but the GC-reten- 
tion times of the two synthetic $\mathrm{C} 8$ diastereomers, which were quite similar, differed markedly from that of the natural 5,9E259B. Thus, the postulated structure of 259B is not correct and further study will be required, in particular as to whether and where the side-chain at $\mathrm{C} 5$ is branched.

\section{Supporting Information}

\section{Supporting Information File 1}

Experimental. Details of experimental procedures and data for characterisation of new compounds. [http://www.beilstein-journals.org/bjoc/content/ supplementary/1860-5397-4-6-S1.doc]

\section{Acknowledgments}

We would like to thank the Department of Education and Learning DEL for a studentship to Angela Nelson. The research at NIH was supported by the intramural funds of NIDDK.

\section{References}

1. Michael, J. P. Nat. Prod. Rep. 2007, 24, 191-222. doi:10.1039/ b509525p

2. Daly, J. W.; Spande, T. F.; Garraffo, H. M. J. Nat. Prod. 2005, 68, 1556-1575. doi:10.1021/np0580560

3. Tsuneki, H.; You, Y.; Toyooka, N.; Kagawa, S.; Kobayashi, S.; Sasaoka, T.; Nemoto, H.; Kimura, I.; Dani, J. A. Mol. Pharmacol. 2004, 66, 1061-1069. doi:10.1124/mol.104.000729

4. Daly, J. W.; Nishizawa, Y.; Padgett, W. L.; Tokuyama, T.; Smith, A. L.; Holmes, A. B.; Kibayashi, C.; Aronstam, R. S. Neurochem. Res. 1991, 16, 1213-1218. doi:10.1007/BF00966698

5. Toyooka, N.; Nemoto, H.; Kawasaki, M.; Garraffo, H. M.; Spande, T. F.; Daly, J. W. Tetrahedron 2005, 61, 1187-1198. doi:10.1016/ j.tet.2004.11.060

6. Smith, A. L.; Williams, S. F.; Holmes, A. B.; Hughes, L. R.; Lidert, Z.; Swithenbank, C. J. Am. Chem. Soc. 1988, 110, 8696-8698. doi:10.1021/ja00234a021

7. Watanabe, Y.; lida, H.; Kibayashi, C. J. Org. Chem. 1989, 54, 4088-4097. doi:10.1021/jo00278a020

8. Holmes, A. B.; Smith, A. L.; Williams, S. F.; Hughes, L. R.; Lidert, Z.; Swithenbank, C. J. Org. Chem. 1991, 56, 1393-1405. doi:10.1021/ jo00004a012

9. Collins, I.; Fox, M. E.; Holmes, A. B.; Williams, S. F.; Baker, R.; Forbes, I. J.; Thompson, M. J. Chem. Soc., Perkin Trans. 1 1991, 175-182. doi:10.1039/P19910000175

10. Shishido, Y.; Kibayashi, C. J. Org. Chem. 1992, 57, 2876-2883. doi:10.1021/jo00036a024

11. Jefford, C. W.; Sienkiewicz, K.; Thornton, S. R. Helv. Chim. Acta 1995, 78, 1511-1524. doi:10.1002/hlca.19950780610

12. Ahman, J.; Somfai, P. Tetrahedron 1995, 51, 9747-9756. doi:10.1016/ 0040-4020(95)00558-P

13. Taber, D. F.; Rahimizadeh, M.; You, K. K. J. Org. Chem. 1995, 60, 529-531. doi:10.1021/jo00108a011
14. Michael, J. P.; Gravestock, D. Synlett 1996, 981-982. doi:10.1055/s1996-5646

15. Comins, D. L.; LaMunyon, D. H.; Chen, X. J. Org. Chem. 1997, 62, 8182-8187. doi:10.1021/jo971448u

16. Michael, J. P.; Gravestock, D. Pure Appl. Chem. 1997, 69, 583-588. doi:10.1351/pac199769030583

17. Michael, J. P.; Gravestock, D. S. Afr. J. Chem. 1998, 51, 146-157.

18. Bardou, A.; Celerier, J.-P.; Lhommet, G. Tetrahedron Lett. 1998, 39 , 5189-5192. doi:10.1016/S0040-4039(98)01040-5

19. Michael, J. P.; Gravestock, D. Eur. J. Org. Chem. 1998, 865-870. doi:10.1002/(SICI)1099-0690(199805)1998:5<865::AIDEJOC865>3.0.CO;2-3

20. Kawakami, T.; Ohtake, H.; Arakawa, H.; Okachi, T.; Imada, Y.; Murahashi, S.-I. Org. Lett. 1999, 1, 107-110. doi:10.1021/ol9905755

21. Michel, P.; Rassat, A.; Daly, J. W.; Spande, T. F. J. Org. Chem. 2000, 65, 8908-8918. doi:10.1021/jo000666b

22. Michael, J. P.; Gravestock, D. J. Chem. Soc., Perkin Trans. 12000 , 1919-1928. doi:10.1039/b001853h

23. Shu, C.; Alcudia, A.; Yin, J.; Liebeskind, L. S. J. Am. Chem. Soc. 2001, 123, 12477-12487. doi:10.1021/ja011635g

24. Smith, A. B., III; Kim, D.-S. Org. Lett. 2004, 6, 1493-1495. doi:10.1021/ ol049601b

25. Toyooka, N.; Kawasaki, M.; Nemoto, H.; Awale, S.; Tezuka, Y.; Kadota, S. Synlett 2005, 3109-3110. doi:10.1055/s-2005-921911

26. Smith, A. B., III; Kim, D.-S. Org. Lett. 2005, 7, 3247-3250. doi:10.1021/ ol0510264

27. Toyooka, N.; Kawasaki, M.; Nemoto, H.; Daly, J. W.; Spande, T. F.; Garraffo, H. M. Heterocycles 2005, 65, 5-8.

28. Toyooka, N.; Zhou, D. J.; Nemoto, H.; Garraffo, H. M.; Spande, T. F.; Daly, J. W. Heterocycles 2006, 70, 541-548.

29. Smith, A. B., III; Kim, D.-S. J. Org. Chem. 2006, 71, 2547-2557. doi:10.1021/jo052314g

30. Toyooka, N.; Nemoto, H.; Tsuneki, H. J. Synth. Org. Chem., Jpn. 2006, 64, 49-60.

31. Toyooka, N.; Dejun, Z.; Nemoto, H.; Garraffo, H. M.; Spande, T. F.; Daly, J. W. Tetrahedron Lett. 2006, 47, 577-580. doi:10.1016/ j.tetlet.2005.11.047

32. Toyooka, N.; Dejun, Z.; Nemoto, H.; Garraffo, H. M.; Spande, T. F.; Daly, J. W. Tetrahedron Lett. 2006, 47, 581-582. doi:10.1016/ j.tetlet.2005.11.046

33. Toyooka, N.; Kobayashi, S.; Zhou, D.; Tsuneki, H.; Wada, T.; Sakai, H.; Nemoto, H.; Sasaoka, T.; Garraffo, H. M.; Spande, T. F.; Daly, J. W. Bioorg. Med. Chem. Lett. 2007, 17, 5872-5875. doi:10.1016/ j.bmcl.2007.08.045

34. Toyooka, N.; Zhou, D.; Nemoto, H.; Garraffo, H. M.; Spande, T. F.; Daly, J. W. Beilstein J. Org. Chem. 2007, 3, No. 29. doi:10.1186/18605397-3-29

35. Kobayashi, S.; Toyooka, N.; Zhou, D.; Tsuneki, H.; Wada, T.; Sasaoka, T.; Sakai, H.; Nemoto, H.; Garraffo, H. M.; Spande, T. F.; Daly, J. W. Beilstein J. Org. Chem. 2007, 3, No. 30. doi:10.1186/18605397-3-30

36. Suzuki, M.; Kawagishi, T.; Yanagisawa, A.; Suzuki, T.; Okamura, N.; Noyori, R. Bull. Chem. Soc. Jpn. 1988, 61, 1299-1312. doi:10.1246/ bcsj.61.1299

37. McAlonan, H.; Potts, D.; Stevenson, P. J.; Thompson, N. Tetrahedron Lett. 2000, 41, 5411-5414. doi:10.1016/S0040-4039(00)00868-6

38. Potts, D.; Stevenson, P. J.; Thompson, N. Tetrahedron Lett. 2000, 41, 275-278. doi:10.1016/S0040-4039(99)02034-1

39. McAlonan, H.; Stevenson, P. J.; Thompson, N.; Treacy, A. B. Synlett 1997, 1359-1360. doi:10.1055/s-1997-1052 
40. Hoffmann, R. W. Chem. Rev. 1989, 89, 1841-1860. doi:10.1021/ cr00098a009

41. Grubbs, R. H. Tetrahedron 2004, 60, 7117-7140. doi:10.1016/ j.tet.2004.05.124

42. Grubbs, R. H.; Chang, S. Tetrahedron 1998, 54, 4413-4450. doi:10.1016/S0040-4020(97)10427-6

43. Edwards, O. E.; Greaves, A. M.; Sy, W.-W. Can. J. Chem. 1988, 66, 1163-1172. doi:10.1139/v88-191

44. Hart, D. J.; Tsai, Y. M. J. Org. Chem. 1982, 47, 4403-4409. doi:10.1021/jo00144a003

45. Armstrong, P.; O'Mahony, G.; Stevenson, P. J.; Walker, A. D. Tetrahedron Lett. 2005, 46, 8109-8111. doi:10.1016/ j.tetlet.2005.09.133

46. Harris, J. M.; Padwa, A. J. Org. Chem. 2003, 68, 4371-4381. doi:10.1021/jo034324s

47. Kurihara, T.; Matsubara, Y.; Osaki, H.; Harusawa, S.; Yoneda, R. Heterocycles 1990, 30, 885-896.

48. Dess, D. B.; Martin, J. C. J. Org. Chem. 1983, 48, 4155-4156. doi:10.1021/jo00170a070

49. Stork, G.; Zhao, K. Tetrahedron Lett. 1989, 30, 2173-2174. doi:10.1016/S0040-4039(00)99640-0

50. Takahashi, S.; Kuroyama, Y.; Sonogashira, K.; Hagihara, N. Synthesis 1980, 627-630. doi:10.1055/s-1980-29145

51. Tokuyama, T.; Shimada, A.; Garraffo, H. M.; Spande, T. F.; Daly, J. W. Heterocycles 1998, 49, 427-436.

\section{License and Terms}

This is an Open Access article under the terms of the Creative Commons Attribution License

(http://creativecommons.org/licenses/by/2.0), which permits unrestricted use, distribution, and reproduction in any medium, provided the original work is properly cited.

The license is subject to the Beilstein Journal of Organic Chemistry terms and conditions:

(http://www.beilstein-journals.org/bjoc)

The definitive version of this article is the electronic one which can be found at: $\underline{\text { doi:10.1186/1860-5397-4-6 }}$ 